\title{
OLDER PEOPLE'S PREFERENCES FOR SELF-INVOLVEMENT IN DECISION-MAKING IF FACED WITH SERIOUS ILLNESS
}

\author{
As preferências de pessoas idosas pelo autoenvolvimento \\ na tomada de decisão numa situação de doença grave
}

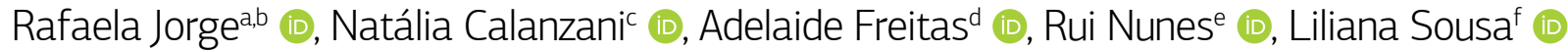

OBJECTIVES: To examine older people's preferences for self-involvement in end-of-life care decision-making in scenarios of mental capacity (competency) and incapacity, and to identify associated factors. METHODS: A cross-sectional survey was conducted including 400 individuals aged 60+ years living in the city of Belo Horizonte, Brazil. RESULTS: Among 400 respondents, $95.3 \%$ preferred self-involvement when capable (due to the high percentage, associated factors were not calculated) and $64.5 \%$ preferred self-involvement when incapable through, for example, a living will. Considering that participants could choose multiple answers, the most frequent combinations in the capacity scenario were "yourself" and "other relatives" (76.8\%) and "yourself" and "the doctor" (67.8\%). In the incapacity scenario, the most frequent combinations were "yourself" and "other relatives" (usually their children and, less often, their grandchildren) (59.3\%) and "yourself" and "the doctor" (48.5\%). Three factors were associated with a preference for self-involvement in an incapacity scenario. Those who were married or had a partner (widowed; adjusted odds ratio $[A O R]=0.37 ; 95 \%$ confidence interval [CI] 0.19-0.68) and those who were male (female; AOR = 0.62; 95\%Cl 0.38-1.00) were less likely to prefer self-involvement. Those who were younger, as in age bands 60-69 years (80+; $\mathrm{AOR}=2.35 ; 95 \% \mathrm{Cl} 1.20-4.58)$ and 70-79 years $(80+; \mathrm{AOR}=2.45 ; 95 \% \mathrm{Cl} 1.21-4.94)$, were more likely to prefer self-involvement. CONCLUSIONS: Most participants preferred self-involvement in both scenarios of capacity and incapacity. Preference for self-involvement was higher in the scenario of capacity, while preference for the involvement of other relatives (usually their children) was greater in the scenario of incapacity. KEYWORDS: aged; palliative care; decision making; mental competency.

OBJETIVOS: O objetivo deste estudo foi examinar as preferências de pessoas idosas pelo autoenvolvimento na tomada de decisões nos cuidados de saúde em fim de vida em cenários de capacidade e incapacidade mental (competência), e identificar os fatores associados. METODOLOGIA: Foi realizado um estudo transversal, com 400 indivíduos, com idade 60 anos ou mais, residentes na cidade de Belo Horizonte, Brasil. RESULTADOS: Entre os 400 entrevistados, 95,3\% preferiram o autoenvolvimento, quando capazes, na tomada de decisões (devido ao alt percentual, fatores associados não foram caculados); e 64,5\% preferiram o autoenvolvimento, quando incapazes de tomar decisões, por meio, por exemplo, de um testamento em vida. Considerando que os participantes puderam escolher mais de uma resposta, as combinações mais frequentes para o cenário de capacidade foram: participantes e outros familiares (76,8\%); e participantes e médicos (67,8\%). No cenário de incapacidade, as combinações mais frequentes foram: participantes e outros familiares (geralmente filhos e netos) (59,3\%); e participantes e médicos (48,5\%). Três fatores foram associados à preferência pelo autoenvolvimento em um cenário de incapacidade. Aqueles que eram casados ou com companheiro (viúvo; odds ratio ajustada (AOR) = 0,37; intervalo de confiança (IC) 95\% 0,19-0,68) e os homens (mulheres; AOR = 0,62; IC95\% 0,38-1,00) foram menos propensos a preferir o autoenvolvimento. Os mais jovens: 60-69 anos (80+; AOR = 2,35; IC95\% 1,20-4,58) and 70-79 anos (80+; AOR = 2,45; IC95\% 1,21$4,94)$ foram mais prováveis de preferir o autoenvolvimento. CONCLUSÕES: A maioria dos participantes preferiu o autoenvolvimento em ambos os cenários de capacidade e incapacidade. A preferência pelo autoenvolvimento foi maior no cenário de capacidade, enquanto a preferência pelo envolvimento de outros familiares (geralmente filhos) foi maior no cenário de incapacidade.

PALAVRAS-CHAVE: idoso; cuidados paliativos; tomada de decisões; competência mental.

aDoctoral Program in Gerontology and Geriatrics, University of Aveiro - Aveiro, Portugal.

${ }^{b}$ Abel Salazar Institute of Biomedical Sciences, University of Porto - Porto, Portugal.

Usher Institute of Population Health Sciences and Informatics, Centre for Population Health Sciences, University of Edinburgh - Edinburgh, United Kingdom.

${ }^{d}$ Center for Research \& Development in Mathematics and Applications, Department of Mathematics, University of Aveiro - Aveiro, Portugal.

eFaculty of Medicine of the University of Porto - Porto, Portugal.

fDepartment of Education and Psychology, Center for Health Technology and Services Research, University of Aveiro - Aveiro, Portugal.

Corresponding data:

Rafaela Jorge - Department of Education and Psychology, University of Aveiro - Campus Universitário de Santiago, 3810-193 - Aveiro, Portugal. E-mail: rafaelajorge@outlook.com

Received on: 12/10/2019. Accepted on: 02/08/2020

DOI: $10.5327 / 22447-212320202000089$ 


\section{INTRODUCTION}

Advance directives (ADs) are written documents that give individuals the opportunity to express their own future medical care preferences as insurance against future loss of mental capacity, allowing them to accept or refuse extreme lifesaving measures. ${ }^{1,2}$ Countries such as the United States (US), Mexico, Argentina, the United Kingdom, Belgium, the Netherlands and, more recently, Portugal have AD legislation. ${ }^{2,3}$ In Brazil, there is no AD legislation yet, although discussions have advanced after the issue of Resolution no. $1995 / 2012{ }^{3,4}$ It recognizes the patients' right to express preferences for care and treatment by asking what they wish to receive in a situation of inability to make decisions and allows them to designate a representative for that purpose. ${ }^{4}$

Previous studies show significant variability among older persons regarding end-of-life (EOL) care decision-making. ${ }^{5}$ Some wish for self-involvement, some report the desire to include physicians and/or family members in the decision-making process, while others wish not to be personally involved (passive participation)..$^{5-9}$ A population-based cross-national survey of preferences and priorities for EOL care decision-making in seven European countries showed that $73 \%$ of participants aged $60-69$ years and $62 \%$ of those aged 70+ years wished for self-involvement in a scenario of mental capacity. ${ }^{2}$ However, in a scenario of mental incapacity, $60 \%$ of respondents aged $60-69$ years and $65 \%$ of those aged $70+$ years would rather not be self-involved through, for example, a living will. ${ }^{2}$ There are reports on factors that affect preferences for decision-making showing that older persons, compared to younger persons, prefer to be less involved in health decisions. ${ }^{2,5,7,10,11}$ Women and those with higher levels of literacy prefer a more active role (self-involvement). ${ }^{10,11}$

It is important to adapt EOL care policies to different social, economic, and cultural contexts, ${ }^{2}$ as well as to people's needs, preferences, and priorities. In recent decades, there has been a growth in palliative care in Brazil and a growing debate about EOL issues. ${ }^{12}$ However, the World Health Organization shows that palliative care in Brazil is relatively limited compared with the size of its population. ${ }^{13}$ As a result, many patients do not have access to EOL care or are even unaware of its existence. Furthermore, conversations about EOL care are still a taboo in Brazilian society, which makes it difficult for people to express their EOL care preferences to their family members or to physicians. ${ }^{14}$ Finally, the lack of legal regulation for EOL practices in Brazil (such as specific legislation for $\mathrm{ADs}$ ) may lead to the risk of prosecution for providers which may compromise EOL care provision. ${ }^{12,14}$ Therefore, policymakers in Brazil should increase efforts to ensure that patients' EOL preferences are respected.
To our knowledge, there have been no studies in Brazil investigating preferences for self-involvement in a situation of serious illness. Based on the need for more evidence to guide national policies and clinical practices, this study aimed to examine older people's preferences for self-involvement in EOL care decision-making in scenarios of mental capacity and incapacity. Furthermore, it investigated factors associated with preference for self-involvement in a scenario of incapacity.

\section{METHODS}

\section{Study design and setting}

A cross-sectional face-to-face survey was conducted in Belo Horizonte, capital of the state of Minas Gerais, southeastern Brazil. It was informed by the PRISMA survey of preferences and priorities for EOL care. ${ }^{2}$

\section{Sample}

The study sample consisted of older people (aged 60+ years). The sample was obtained considering the Brazilian population distribution by age and gender according to the 2010 Brazilian Demographic Census. According to the Census, there were 299,177 older people (aged 60+ years) living in the city of Belo Horizonte. Based on the Krejcie and Morgan table (1970), ${ }^{15}$ for a 95\% confidence level, considering a conservative scenario $(p=0.5)$, the required sample size (with a margin of error of 5\%) was approximately 400 participants. Quota sampling was adopted in order to consider age distribution by age bands ( $60-69$ years; $70-79$ years; $80+$ years) and gender. The number of respondents in each subsample (stratum) was proportionally calculated to ensure that the sample distribution by age bands and gender was proportional to the sample universe/frame.

\section{Data collection}

Data were collected between February and July 2015. The population was sampled from well-established social programs developed by Belo Horizonte's City Council that focused on assisting community-dwelling older people (by providing services and activities such as physical exercise, computing, handicraft, and singing lessons). This strategy ensured that potential participants were living in the community as opposed to an institution (similar to the population sampled in the PRISMA surveys)., 2,16

Participants were sampled from the Reference Center for Older People (CRPI) and 10 older people's community-dwelling groups from the Reference Center of Social Services 
(CRAS), managed by the City Council's Sub-Secretariat of Social Services (SMAAS). The SMAAS helped to select ten different groups which covered all nine geographical regions in the city of Belo Horizonte (Barreiro, Centro Sul [Mid-South], Leste [East], Nordeste [Northeast], Noroeste [Northwest], Norte [North], Oeste [West], Pampulha, and Venda Nova) and included older people with different levels of social deprivation. The study was approved by the CRPI's coordinator and by the SMAAS Secretary-General.

The study was introduced to potential participants in those 11 centers (by the lead author and study collaborators). The lead author had a desk in those centers and was available to answer questions from those who showed interest in participating in the study. These initial conversations were also an opportunity for the lead researcher to confirm eligibility. If potential participants were eligible and were still interested after asking questions about the study, then they received detailed study information and a consent form. All questionnaires were administered face to face by the first author, who had received methodological guidance from members of the PRISMA Research Team based at King's College London. Interviews were then conducted until 400 participants were included (which is why data collection lasted almost six months). The following inclusion criteria were used: aged 60+ years; living in the city of Belo Horizonte; and being able to give informed consent. With the collaboration of the professionals in the centers, the users considered not to be oriented in time and space were excluded.

\section{The survey tool}

The questionnaire was developed as part of PRISMA, ${ }^{2}$ which covered England, Flanders (the Dutch speaking part of Belgium), Germany, Italy, the Netherlands, Spain, and Portugal.

The Portuguese version of the PRISMA questionnaire was culturally adapted to the Brazilian Portuguese language. ${ }^{17}$ This study differed from the original PRISMA methodology adopted in Europe in four ways. First, the questionnaire was administered face to face instead of over the telephone as recommended by Brazilian palliative care specialists due to the sensitive nature of the topic. Second, the hypothetical scenario of advanced illness was broadened to include other relevant conditions in addition to cancer. Third, similarly to the English questionnaire but differing from the other European versions, a question about the participant's ethnicity was included. Finally, the Brazilian survey focused on the older population as chronic/life-limiting conditions are more common among older age groups.
The Brazilian version of the questionnaire examined preferences and priorities for EOL care in a situation of serious illness (such as cancer, dementia, Parkinson's disease, chronic obstructive pulmonary disease, heart disease, renal failure, or osteoarthritis), with less than 1 year to live. The questionnaire consisted of two parts. The first part included 10 questions on preferences regarding information, care options, symptoms and problems, decision-making involvement, place of death, and priorities in treatment, care goals, information and decision-making., ${ }^{2,17}$ In the second part, participants were asked about their experiences with illness, death, and dying, and sociodemographic information. ${ }^{2,17}$ Publications on other topics covered by the questionnaire are available elsewhere. ${ }^{18-20}$

Participants indicated preferences for self-involvement in EOL care by answering the following question: "Keeping in mind a situation of serious illness with less than 1 year to live, please consider that you were able to make decisions. Who would you like to make decisions about your care? Please choose as many as apply, you can choose more than one." Answer options were "yourself," “your spouse or partner," "other relatives," "friends," "the doctor," "others," "don't know," and "refusal/prefer not to say."

This was followed by this question: "If you had lost your ability to make decisions, who would you like to make decisions about your care? Please choose as many as apply, you can choose more than one." Answer options were "yourself, by specifying your wishes before losing ability - for example, in a living will," "your spouse or partner," "other relatives," "friends," "the doctor," "others," "don't know," and "refusal/ prefer not to say."

\section{Ethical approval and consent to participate}

This study was approved by the Ethics Committee of the Department of Social Sciences and Health of the School of Medicine of the University of Porto/ Portugal (PCEDCSSFMUP no. 15/2014) and by the Research Ethics Committee of the Municipal Department of Health of Belo Horizonte (SMSA-BH) (CAAE no. 40740914.3.0000.5140). After asking questions and clarifying any potential concerns due to the nature of the topic, all who agreed to participate signed a consent form.

\section{Analysis}

Raw percentages were calculated for respondents and decision-making answer options for the scenarios of capacity and incapacity, according to age bands and gender. For the incapacity scenario, answers were converted into a binary score, with a score 1 assigned to participants who chose self-involvement (independently of their choices regarding other 
answer options) and a score 0 to those who did not choose self-involvement. This binary variable was the dependent variable. Bivariate analysis was used to examine the effect of independent variables in the outcome variable (19 independent variables were identified during the first three stages of survey development as relevant to EOL care priorities and preferences) ${ }^{16}$ (Figure 1). Estimated odds ratios (ORs) were reported. Independent variables found to be statistically significant $(\mathrm{P}$-value $<0.10)$ were included in a model in the multivariate analysis. Logistic binomial regression was used, and adjusted odds ratios (AORs) were calculated (with 95\% confidence intervals) in order to identify significant categorical factors associated with the outcome variable (self-involvement vs. no self-involvement). Although the analyses focused on the interpretation of significant factors, goodness of fit for the final model was assessed using the Hosmer-Lemeshow test. All statistical analyses were performed using IBM SPSS Statistics software, version 23.0 for Windows.

Similar analyses for the capacity scenario were initially planned but not carried out due to observed response distributions (see Results).

\section{RESULTS}

Four hundred older adults were interviewed. Nineteen percent reported having been seriously ill in the past five years and $66 \%$ had cared for a close relative or a friend in the last months of life (Table 1).

For the capacity scenario, $95.3 \%$ of respondents preferred self-involvement, with lower percentages found among those aged $80+$ years (Table 2). This was followed by "other relatives" (usually their children and, less often, their grandchildren) (80.8\%) and "the doctor" (71.3\%). Across the whole sample, only $32 \%$ of respondents would prefer the involvement of a spouse or partner in their EOL care decision-making. The proportion of women wanting the participation of a spouse or partner in decision-making was lower than that of men (Table 2). Considering that participants could choose multiple answers, the most frequent combinations were "yourself" and "other relatives" (76.8\%) and "yourself" and "the doctor" (67.8\%).

For the incapacity scenario, $64.5 \%$ preferred self-involvement in the event of their future incapacity, for example, through the use of a living will (Table 2). "Other relatives" was the most frequently chosen answer (92.3\%; higher among women compared to men), followed by "the doctor" (76.8\%; higher among women) and then "yourself" (64.5\%; higher among women). Conversely, the proportion of participants choosing spouse/partner involvement was higher among men. Considering that participants could choose several answer options, the most frequent combinations were "yourself" and "other relatives" (usually their children and, less often, their grandchildren) (59.3\%); and "yourself" and "the doctor" (48.5\%).

Of the potential 19 independent variables (Figure 1), six potential explanatory variables were included in the multivariate analysis.

Participants who were married or had a partner were less likely to wish to be self-involved in decision-making in a scenario of incapacity when compared to those widowed (AOR $=0.37 ; 95 \% \mathrm{CI} 0.19-0.68)$. Participants in the age bands 60-69 (AOR $=2.35$; 95\%CI 1.20-4.58) and 70-79 years $(\mathrm{AOR}=2.45 ; 95 \% \mathrm{CI} 1.21-4.94)$ preferred self-involvement more often than those aged $80+$ years. Men were less likely to prefer self-involvement in comparison with women $(\mathrm{AOR}=0.62 ; 95 \% \mathrm{CI}$ 0.38-1.00) (Table 3).

\section{DISCUSSION}

This study examined older people's preferences for self-involvement in EOL care decision-making in scenarios of mental capacity and incapacity. Most respondents preferred self-involvement both in the scenarios of capacity and incapacity, and wished to involve their spouse or partner and doctor in decision-making. A preference for self-involvement was higher in the scenario of capacity, while a preference for the involvement of other relatives (usually their children) was greater in the scenario of incapacity. These findings indicate

\begin{tabular}{|l|c|}
\hline $\begin{array}{l}\text { Socio-demographic } \\
\text { variables }\end{array}$ & $\begin{array}{r}\text { Age bands, gender, education, marital status, religion, ethnicity, activities in last } 7 \text { days, financial } \\
\text { hardship, living arrangements (i.e., living alone or with others), and health }\end{array}$ \\
\hline $\begin{array}{l}\text { Preferences and } \\
\text { priorities }\end{array}$ & $\begin{array}{r}\text { Preferred place of death; treatment priority of a) improving quality of life, b) extending life, or c) } \\
\text { improving quality of life and extending life being equally important }\end{array}$ \\
\hline $\begin{array}{l}\text { Experiential } \\
\text { variables }\end{array}$ & $\begin{array}{r}\text { Being diagnosed with a serious illness in last } 5 \text { years; diagnosis of a close relative/friend in last } 5 \text { years; } \\
\text { death of a close relative or friend in last } 5 \text { years; caring for a relative or friend in their last few months of life }\end{array}$ \\
\hline
\end{tabular}

Figure 1 Three categories involving a total of 19 independent variables were examined: socio-demographic variables, preferences and priorities, and experiential variables. 
a model of shared decision-making, including the participation of patients, family members, and doctors. In Brazil, such models have yet to be promoted and implemented..$^{21,22}$

In the capacity scenario, respondents showed greater preferences for self-involvement when compared with PRISMA results in seven European countries. ${ }^{2}$ In the incapacity

Table 1 Respondents' characteristics.

\begin{tabular}{|c|c|c|}
\hline Variables & $\mathbf{n}$ & $\%$ \\
\hline \multicolumn{3}{|l|}{ Age bands } \\
\hline 60-69 years & 217 & 54.3 \\
\hline 70-79 years & 121 & 30.3 \\
\hline $80+$ years & 62 & 15.5 \\
\hline \multicolumn{3}{|l|}{ Gender } \\
\hline Female & 241 & 60.3 \\
\hline Male & 159 & 39.7 \\
\hline \multicolumn{3}{|l|}{ Education } \\
\hline No formal schooling & 30 & 7.5 \\
\hline Up to 4 years & 149 & 37.3 \\
\hline Up to 8 years & 54 & 13.5 \\
\hline Up to 12 years & 122 & 30.5 \\
\hline Higher education & 45 & 11.3 \\
\hline \multicolumn{3}{|l|}{ Marital status } \\
\hline Single & 61 & 15.3 \\
\hline Married or with a partner & 167 & 41.8 \\
\hline Divorced or separated & 50 & 12.5 \\
\hline Widowed & 122 & 30.5 \\
\hline \multicolumn{3}{|l|}{ Religion } \\
\hline Roman Catholic & 267 & 66.8 \\
\hline Protestantism/Evangelical & 63 & 15.8 \\
\hline Spiritism/Afro-Brazilian & 37 & 9.3 \\
\hline Other & 11 & 2.8 \\
\hline No religion & 22 & 5.5 \\
\hline \multicolumn{3}{|l|}{ Ethnicity* } \\
\hline White & 114 & 28.5 \\
\hline Black & 63 & 15.8 \\
\hline Brown and other (1: Yellow; 1: Indigenous) & 223 & 55.8 \\
\hline
\end{tabular}

scenario, Brazilian participants reported greater preferences for self-involvement when compared with their counterparts in Belgium, Italy, the Netherlands, Portugal, and Spain (where the majority of older participants reported not wanting to be self-involved). ${ }^{2}$ Findings in Brazil were more similar to those obtained in Germany and England. ${ }^{2}$ A recent study carried
Variables

n

$\%$

Activities in last 7 days (Multiple answer options allowed)

\begin{tabular}{l|c|c}
\hline $\begin{array}{l}\text { In education (not paid for by employer) } \\
\text { even if on vacation }\end{array}$ & 26 & 6.5 \\
\hline Unemployed & 41 & 10.3 \\
\hline Permanently sick or disabled & 5 & 1.3 \\
\hline In paid work & 136 & 34.0 \\
\hline Retired & 323 & 80.8 \\
\hline Pensioner & 102 & 25.5 \\
\hline $\begin{array}{l}\text { Doing housework, looking after children, } \\
\text { or others }\end{array}$ & 34 & 8.5 \\
\hline Other & 38 & 9.5 \\
\hline
\end{tabular}

Financial hardship

\begin{tabular}{|c|c|c|}
\hline Very difficult on present income & 24 & 6.0 \\
\hline Difficult on present income & 55 & 13.8 \\
\hline Coping on present income & 207 & 51.7 \\
\hline Living comfortably on present income & 114 & 28.5 \\
\hline \multicolumn{3}{|l|}{ Living arrangements } \\
\hline Living alone & 75 & 18.8 \\
\hline \multicolumn{3}{|l|}{ Health } \\
\hline Fair & 76 & 19.0 \\
\hline Good & 214 & 53.5 \\
\hline Very good & 110 & 27.5 \\
\hline \multicolumn{3}{|l|}{ Experience of illness, death, and dying } \\
\hline $\begin{array}{l}\text { Close relative/friend seriously ill in last } \\
5 \text { years }\end{array}$ & 299 & 74.8 \\
\hline $\begin{array}{l}\text { Death of close relative/friend in last } \\
5 \text { years }\end{array}$ & 270 & 67.5 \\
\hline Diagnosed with serious illness in last 5 years & 76 & 19.0 \\
\hline $\begin{array}{l}\text { Cared for close relative/friend in last } \\
\text { months of life }\end{array}$ & 264 & 66.0 \\
\hline
\end{tabular}

*Ethnicity categories were obtained from the official Brazilian Census. Participants were asked to choose among five categories (white [branca], brown [parda], black [preta], yellow [amarela], and indigenous [indígena]). 
out in southern Brazil that examined older persons' preferences for decision-making (without mentioning a terminal condition) showed that $30.9 \%$ would like to decide on their own, while $57.4 \%$ would prefer to ask for advice ("always seek for advice but your own opinion prevails" or "decide with spouse"). ${ }^{23}$

In this study, the high rates of preference for self-involvement in the scenario of capacity may have several explanations.

Table 2 Self-involvement preferences for capacity and incapacity scenarios according to age bands and gender.

\begin{tabular}{|c|c|c|c|c|c|c|c|}
\hline & \multicolumn{3}{|c|}{ Age bands, Male } & \multicolumn{3}{|c|}{ Age bands, Female } & \multirow{2}{*}{ Total } \\
\hline & $60-69$ & 70-79 & $80+$ & $60-69$ & 70-79 & $80+$ & \\
\hline \multicolumn{8}{|l|}{ Capacity scenario } \\
\hline \multicolumn{8}{|l|}{ Self-involvement preferences } \\
\hline Self-involvement & $90(96.8 \%)$ & 45 (95.7\%) & 17 (89.5\%) & $119(96.0 \%)$ & $72(97.3 \%)$ & 38 (88.4\%) & $381(95.3 \%)$ \\
\hline No self-involvement & $3(3.2 \%)$ & $2(4.3 \%)$ & $2(10.5 \%)$ & $5(4.0 \%)$ & $2(2.7 \%)$ & $5(11.6 \%)$ & $19(4.7 \%)$ \\
\hline \multicolumn{8}{|c|}{ Multiple answer options allowed } \\
\hline Yourself & $90(96.8 \%)$ & $45(95.7 \%)$ & 17 (89.5\%) & $119(96.0 \%)$ & $72(97.3 \%)$ & 38 (88.4\%) & $381(95.3 \%)$ \\
\hline Your spouse or partner & $51(54.8 \%)$ & $25(53.2 \%)$ & 9 (47.4\%) & $24(19.4 \%)$ & $16(21.6 \%)$ & $3(7.0 \%)$ & $128(32.0 \%)$ \\
\hline Other relatives & $73(78.5 \%)$ & $36(76.6 \%)$ & $15(78.9 \%)$ & 107 (86.3\%) & $55(74.3 \%)$ & $37(86.0 \%)$ & $323(80.8 \%)$ \\
\hline Friends & $20(21.5 \%)$ & 9 (19.1\%) & $1(5.3 \%)$ & $39(31.5 \%)$ & $27(36.5 \%)$ & $6(14.0 \%)$ & $102(25.5 \%)$ \\
\hline The doctor & $56(60.2 \%)$ & $38(80.9 \%)$ & 15 (78.9\%) & $83(66.9 \%)$ & $57(77.0 \%)$ & $36(83.7 \%)$ & $285(71.3 \%)$ \\
\hline Others & $1(1.1 \%)$ & $0(-)$ & $1(5.3 \%)$ & $1(0.8 \%)$ & $1(1.4 \%)$ & $1(2.3 \%)$ & $5(1.3 \%)$ \\
\hline $\begin{array}{l}\text { Self-involvement + } \\
\text { Other relatives }\end{array}$ & $72(77.4 \%)$ & $34(72.3 \%)$ & $14(73.7 \%)$ & $102(82.3 \%)$ & $53(72.6 \%)$ & $32(74.4 \%)$ & $307(76.8 \%)$ \\
\hline $\begin{array}{l}\text { Self-involvement + } \\
\text { The doctor }\end{array}$ & $54(58.1 \%)$ & 37 (78.7\%) & $13(68.4 \%)$ & $80(64.5 \%)$ & $55(74.3 \%)$ & $32(74.4 \%)$ & $271(67.8 \%)$ \\
\hline \multicolumn{8}{|l|}{ Incapacity scenario } \\
\hline \multicolumn{8}{|l|}{ Self-involvement preferences } \\
\hline Self-involvement & $53(57.0 \%)$ & $25(53.2 \%)$ & $6(31.6 \%)$ & 90 (72.6\%) & $58(78.4 \%)$ & $26(60.5 \%)$ & $258(64.5 \%)$ \\
\hline No self-involvement & $40(43.0 \%)$ & $22(46.8 \%)$ & $13(68.4 \%)$ & $34(27.4 \%)$ & $16(21.6 \%)$ & $17(39.5 \%)$ & $142(35.5 \%)$ \\
\hline \multicolumn{8}{|c|}{ Multiple answer options allowed } \\
\hline $\begin{array}{l}\text { Yourself, by specifying your } \\
\text { wishes before losing ability } \\
\text { (e.g., in a living will) }\end{array}$ & $53(57.0 \%)$ & 25 (53.2\%) & $6(31.6 \%)$ & $90(72.6 \%)$ & $58(78.4 \%)$ & $26(60.5 \%)$ & $258(64.5 \%)$ \\
\hline Your spouse or partner & $54(58.1 \%)$ & $28(59.6 \%)$ & $10(52.6 \%)$ & $31(25.0 \%)$ & $20(27.0 \%)$ & $4(9.3 \%)$ & $147(36.8 \%)$ \\
\hline Other relatives & $78(83.9 \%)$ & $43(91.5 \%)$ & $17(89.5 \%)$ & $120(96.8 \%)$ & $69(93.2 \%)$ & $42(97.7 \%)$ & $369(92.3 \%)$ \\
\hline Friends & $21(22.6 \%)$ & $11(23.4 \%)$ & $3(15.8 \%)$ & $42(33.9 \%)$ & $28(37.8 \%)$ & $10(23.3 \%)$ & $115(28.8 \%)$ \\
\hline The doctor & $64(68.8 \%)$ & 38 (80.9\%) & $15(78.9 \%)$ & $90(72.6 \%)$ & $64(86.5 \%)$ & $36(83.7 \%)$ & 307 (76.8\%) \\
\hline Others & $0(-)$ & $1(2.1 \%)$ & $1(5.3 \%)$ & $1(0.8 \%)$ & $1(1.4 \%)$ & $1(2.3 \%)$ & $5(1.3 \%)$ \\
\hline $\begin{array}{l}\text { Self-involvement + } \\
\text { Other relatives }\end{array}$ & $43(46.2 \%)$ & $23(48.9 \%)$ & $6(31.6 \%)$ & $86(69.4 \%)$ & $54(73.0 \%)$ & 25 (58.1\%) & $237(59.3 \%)$ \\
\hline $\begin{array}{l}\text { Self-involvement + } \\
\text { The doctor }\end{array}$ & $33(35.5 \%)$ & $21(44.7 \%)$ & $5(26.3 \%)$ & $65(52.4 \%)$ & $50(67.6 \%)$ & $20(46.5 \%)$ & 194 (48.5\%) \\
\hline
\end{tabular}


Data collection was performed at centers offering services that promote older people's rights and strengthen their social roles. Therefore, the participants in this study were active older persons who were aware of their rights, who had cared for their health, and still had the capacity to stay involved. The preference for self-involvement in health care decisions may be influenced by experiences with diseases and medical care, the amount of information the individual has received, diagnoses, health status, and type of relationship with health professionals. ${ }^{10,24,25}$ Some studies have also shown that diminished health status and multiple chronic conditions are associated with a preference for less self-involvement. ${ }^{7,10,23}$ Furthermore, cultural aspects, in particular the relationship between patients and physicians, may influence preferences for self-involvement in decision-making. ${ }^{26}$ For instance, Japanese older persons are more likely to have a passive or submissive attitude towards physicians, allowing them to take on a paternalistic role, ${ }^{26}$ while research in western countries, particularly in the US, shows higher preference for self-involvement. ${ }^{26}$ In Brazil, despite increasing discussions on patient autonomy and EOL care (e.g., Resolution 1995/2012 of the Federal Council of Medicine ${ }^{3,4}$ ), EOL care decisions are often made by physicians without the participation of patients. ${ }^{14,27} \mathrm{~A}$ national Brazilian survey showed that patients with advanced cancer (92.7\%) and families (90.7\%) were more likely to agree that do-not-resuscitate (DNR) orders should be discussed with patients when compared with physicians (70.3\%). ${ }^{27}$ These findings show that Brazilian physicians undertake a more paternalistic approach. ${ }^{14,27}$ In our study, when respondents were asked about EOL preferences, they frequently answered "I had never talked about it with anyone" and/or "I had never thought about it." It is possible

Table 3 Self-involvement in decision-making within an incapacity scenario*.

\begin{tabular}{|c|c|c|c|}
\hline \multirow{2}{*}{ Socio-demographic variables } & \multicolumn{2}{|c|}{ Bivariate analysis } & \multirow{2}{*}{$\begin{array}{c}\text { Multivariate analysis } \\
\text { AOR }(95 \% \mathrm{Cl})\end{array}$} \\
\hline & OR $(95 \% \mathrm{Cl})$ & p & \\
\hline \multicolumn{4}{|l|}{ Gender (ref: female) } \\
\hline Male & $0.43(0.28-0.65)$ & $<0.001$ & $0.62(0.38-1.00)$ \\
\hline \multicolumn{4}{|l|}{ Age bands (ref: $80+$ ) } \\
\hline $60-69$ & $1.81(1.02-3.20)$ & 0.04 & $2.35(1.20-4.58)$ \\
\hline 70-79 & 2.05 (1.09-3.84) & 0.02 & $2.45(1.21-4.94)$ \\
\hline \multicolumn{4}{|l|}{ Marital status (ref: widowed) } \\
\hline Single & $0.66(0.33-1.30)$ & 0.23 & $0.59(0.27-1.29)$ \\
\hline Married or with partner & $0.34(0.20-0.57)$ & $<0.001$ & $0.37(0.19-0.68)$ \\
\hline Separated or divorced & $0.14(0.28-1.19)$ & 0.13 & $0.61(0.27-1.35)$ \\
\hline \multicolumn{4}{|l|}{ Health (ref: fair) } \\
\hline Good & $0.48(0.26-0.85)$ & 0.01 & $0.55(0.29-1.03)$ \\
\hline Very good & $0.71(0.37-1.37)$ & 0.31 & 0.79 (0.38-1.59) \\
\hline \multicolumn{4}{|l|}{ Living with children (ref: none) } \\
\hline One & $2.27(0.96-5.35)$ & 0.06 & $2.11(0.83-5.31)$ \\
\hline Two or more & $1.18(0.39-3.51)$ & 0.77 & $1.41(0.43-4.60)$ \\
\hline \multicolumn{4}{|c|}{ Least preferred place of death (ref: own home) } \\
\hline Home of a relative or friend & $0.46(0.22-0.96)$ & 0.03 & $0.50(0.23-1.10)$ \\
\hline Palliative care/hospital ${ }^{* *}$ & $0.71(0.33-1.48)$ & 0.36 & $0.87(0.39-1.91)$ \\
\hline Care home & $0.44(0.22-0.86)$ & 0.01 & $0.51(0.24-1.91)$ \\
\hline
\end{tabular}

AOR: adjusted odds ratio; 95\%Cl: 95\% confidence interval; OR: odds ratio; *only factors found to be significant in the bivariate analysis are shown (i.e., p $[\mathrm{OR}]<0.10$ ); **because only two individuals showed preference for place of death in a "palliative care unit," in subsequent analyses the answers "hospital but not palliative care unit" and "palliative care unit" were combined into a single group. 
that the high percentage of participants who preferred the participation of physicians in the decision-making process was influenced by the fact that preferences for EOL care are rarely discussed in Brazilian society. Therefore, for patients, their doctor's opinion may be crucial. However, we need more studies investigating people's opinions on medical decision-making for EOL care in Brazil.

Due to the high percentage of respondents that demonstrated a preference for self-involvement in the capacity scenario (95.3\%), associated factors were not calculated. In the incapacity scenario, three factors were significantly associated with a preference for self-involvement (with different directions): age bands, gender, and marital status. Those aged 60-69 and 70-79 years (in comparison with those aged $80+$ years) were more likely to prefer self-involvement. Other studies have reported that younger people (compared to older people) and older people (compared to the oldest old) prefer self-involvement more often., ${ }^{2,710,11,23,28}$ Men were less likely to prefer self-involvement compared to women. Research has shown that women (compared to men) have a higher preference for active participation in decision-making across all ages. ${ }^{10,11,23}$ Those who are married or have a partner (in comparison with those widowed) were less likely to prefer to be self-involved. A study in southern Brazil reported that married older persons were more likely to seek out advice for decision-making. ${ }^{23}$ In our study, it is possible that self-involvement was deemed to be less important for married participants because they trusted their partners to make a decision for them if/when they became incapable of doing so. However, this possibility needs to be investigated in future studies that also explore the rationale for preferences across older people.

The study findings are relevant to guide clinical practices and national policies in Brazil. Conversations between physicians and patients should start as early as possible, as having access to information is a requirement for decision-making. ${ }^{20,29}$ Moreover, progressively worsening conditions may make it difficult for the patient to understand information and may therefore hinder the health care professional's ability to respect patient's preferences. It is also critical to ensure that the wishes of those who do not want to be self-involved are respected. Furthermore, public health education campaigns are needed in Brazil to inform the population about self-involvement in decision-making.

It is also important to note that although older people share some attributes regarding involvement in health decisions, this group is also very heterogeneous. ${ }^{5}$ The approach to decision-making among this population should always be individualized according to needs, to how information is understood, and to the willingness of the older person to participate in these decisions. ${ }^{5}$ The process of involving older people in decision-making is more focused on an attentive relationship (with an individual approach and receiving information) than on active participation in decision-making. ${ }^{5}$ Therefore, the participation of older adults in health decisions, regardless of their willingness to be involved, is related to trust, interest, support, and communication. ${ }^{5,10}$

In Brazil, palliative and EOL care decision-making is still a topic that engenders little public discussion. With the rapid aging of the Brazilian population, it is urgent to bring this topic to the public arena and to have evidence which generates discussions to set policies and improve practice.

\section{Limitations and future perspectives}

This study has some limitations. As mentioned above, the participants in this study were active older persons who were aware of their rights, who had cared for their health, and still had the capacity to stay involved. Further studies are required including older people who do not attend such centers and may have different experiences, in order to assess whether their preferences are different. Furthermore, the preferences of older people who are frail and have functional dependency may be underrepresented. Similar to the original PRISMA study, ${ }^{2,16}$ this study did not target older people living in institutions, and it is possible that they would have different views. It is also possible that the study participants had difficulties imagining a situation of severe disease with less than 1 year to live. However, the participants' experiences with serious illness, dying, and death in the past 5 years helped them contextualize the scenario used in the questionnaire. Moreover, physicians were the only health care professionals that were considered in this study; future studies must explicitly include scenarios with other professionals (e.g., nurses, psychologists, and social workers), as health care involves multidisciplinary teamwork. ${ }^{2}$ The city of Belo Horizonte is the Brazilian capital with the third highest proportion of older people. ${ }^{30}$ Our results are likely to be applicable to other Brazilian metropolitan areas. Future studies should also compare patients' preferences with the perception that health care professionals have about their patients' preferences. This could shed light onto possible obstacles or strengths in the patient-professional relationship. More qualitative research is also required in order to better understand older people's preferences in decision-making. Our recruitment approach influenced our ability to calculate response rates and assess non-response bias. Due to the sensitive nature of the topic, after the study was introduced to all potentially eligible participants, it was deemed most appropriate to allow 
them to approach the researcher if they were interested in participating. Only one potential participant who engaged in conversation about the study later decided not to participate (due to a fear of sharing personal information in the consent form with strangers, despite reassurances). The possibility of non-response bias was difficult to ascertain; additional studies including older people are important to allow for comparisons and better understanding of variation in preferences across different subgroups.

\section{CONCLUSION}

To our knowledge, this is the first study carried out in Brazil examining the preferences of older people for EOL care decision-making if faced with advanced illness. The majority of participants wished to be self-involved in decision-making, in both scenarios of capacity and incapacity. In Brazil, where palliative care is still underutilized, studies in this field are crucial to support the development of measures to respect people's preferences and priorities, and to inform relevant training for health care professionals.

\section{ACKNOWLEDGMENTS}

PRISMA was funded by the European Commission's Seventh Framework Programme (contract number: Health-F2-2008-201655) with the overall aim to co-ordinate high-quality international research into end-of-life cancer care. PRISMA aimed to provide evidence and guidance on best practice to ensure that research can measure and improve outcomes for patients and families. PRISMA activities aimed to reflect the preferences and cultural diversities of citizens, the clinical priorities of clinicians, and appropriately measure multidimensional outcomes across settings where end-of-life care is delivered. Principal Investigator: Richard Harding. Scientific Director: Irene J Higginson. PRISMA members: Gwenda Albers, Barbara Antunes, Ana Barros Pinto, Claudia Bausewein, Dorothee Bechinger-English, Hamid Benalia, Emma Bennett, Lucy Bradley, Lucas Ceulemans, Barbara A Daveson, Luc Deliens, Noël Derycke, Martine de Vlieger, Let Dillen, Julia Downing, Michael Echteld, Natalie Evans, Dagny Faksvåg Haugen, Silvia Finetti, Nancy Gikaara, Barbara Gomes, Marjolein Gysels, Sue Hall, Richard Harding, Irene J Higginson, Stein Kaasa, Jonathan Koffman, Pedro Lopes Ferreira, Arantza Meñaca, Johan Menten, Natalia Monteiro Calanzani, Fliss Murtagh, Bregje Onwuteaka-Philipsen, Roeline Pasman, Francesca Pettenati, Robert Pool, Richard A. Powell, Miel Ribbe, Katrin Sigurdardottir, Steffen Simon, Franco Toscani, Bart Van den Eynden, Paul Vanden Berghe, and Trudie van Iersel.

\section{CONFLICT OF INTERESTS}

None declared.

\section{FUNDING}

R.J.was supported by Coordination for the Improvement of Higher Education Personnel (CAPES) (Proc. no. 0905/14-3). A.F.was supported by Science and Technology Foundation (FCT), within project UID/MAT/04106/2019 (CIDMA).

L.S. was supported by National Funds through Science and Technology Foundation (FCT) within CINTESIS, R\&D Unit (reference UID/IC/4255/2019)

\section{REFERENCES}

1. Hunsaker AE, Mann A. An Analysis of the Patient Self-Determination Act of 1990. J Hum Behav Soc Environ. 2013;23(7):841-48. http:// doi.org/10.1080/10911359.2013.809287

2. Daveson BA, Bausewein C, Murtagh FE, Calanzani N, Higginson IJ, Harding R, et al. To be involved or not to be involved: a survey of public preferences for self-involvement in decision-making involving mental capacity (competency) within Europe. Palliat Med. 2013;27(5):418-27. http://doi.org/10.1177/0269216312471883

3. Cogo SB, Lunardi VL. Advance directives: a documentary analysis in the global context. Texto Context Enferm. 2018;27(3). http://doi. org/10.1590/0104-070720180001880014

4. Conselho Federal de Medicina. Resolução CFM no 1.995/2012. Dispõe sobre as diretivas antecipadas de vontade dos pacientes [Internet]. 2012 [accessed on Nov, 10, 2019]. Available from: http://www.portalmedico.org.br/resolucoes/ cfm/2012/1995_2012.pdf

5. Bastiaens H, Van Royen P, Pavlic DR, Raposo V, Baker R. Older people's preferences for involvement in their own care: A qualitative study in primary health care in 11 European countries.
Patient Educ Couns. 2007;68(1):33-42. http://doi.org/10.1016/j. pec.2007.03.025

6. Elkin EB, Kim SHM, Casper ES, Kissane DW, Schrag D. Desire for information and involvement in treatment decisions: Elderly cancer patients' preferences and their physicians' perceptions. J Clin Oncol. 2007;25(33):5275-80. http://doi.org/10.1200/JC0.2007.11.1922

7. Levinson W, Kao A, Kuby A, Thisted RA. Not all patients want to participate in decision making:A national study of public preferences. J Gen Intern Med. 2005;20:531-35. http://doi.org/10.1111/j.15251497.2005.04101.x

8. Paillaud E, Canoui-Poitrine F, Varnier G, Anfasi-Ebadi N, Guery E, Saint-Jean O, et al. Preferences about information and decisionmaking among older patients with and without cancer. Age Ageing. 2017;46(4):665-71. http://doi.org/10.1093/ageing/afw256

9. Higginson IJ, Daveson BA, Morrison RS, Yi D, Meier D, Smith M, et al. Social and clinical determinants of preferences and their achievement at the end of life: Prospective cohort study of older adults receiving palliative care in three countries. BMC Geriatr. 2017;17:271. http:// doi.org/10.1186/s12877-017-0648-4 
10. Say R, Murtagh M, Thomson R. Patients' preference for involvement in medical decision making: A narrative review. Patient Educ Couns. 2006;60(2):102-14. http://doi.org/10.1016/j.pec.2005.02.003

11. Chi WC, Wolff J, Greer R, Dy S. Multimorbidity and decision-making preferences among older adults. Ann Fam Med. 2017;15(6):546-51. http://doi.org/10.1370/afm.2106

12. Soares M. End of life care in Brazil: The long and winding road. Crit Care. 2011;15(1):110. http://doi.org/10.1186/cc9962

13. World Health Organization. World palliative care alliance. Global atlas of palliative care at the end of life [Internet]. Geneva: WHO; 2014 [accessed on Dec. 10, 2019]. Available from: http://www.who. int/cancer/publications/palliative-care-atlas/en/

14. Soares M, Terzi RGG, Piva JP. End-of-life care in Brazil. Intensive Care Med. 2007;33:1014-17. http://doi.org/10.1007/s00134-007-0623-1

15. Krejcie RV, Morgan DW. Determining Sample Size for Research Activities. Educ Psychol Meas. 1970;30(3):607-10. http://doi. org/10.1177/001316447003000308

16. Gomes B, Higginson IJ, Calanzani N, Cohen J, Deliens L, Daveson BA, et al. Preferences for place of death if faced with advanced cancer: A population survey in England, Flanders, Germany, Italy, The Netherlands, Portugal and Spain. Ann Oncol. 2012;23(8):2006-15. http://doi.org/10.1093/annonc/mdr602

17. Jorge R, Sousa L, Nunes R. Preferences and priorities for end-of-life care of older people: cross-cultural adaptation to Brazil. Geriatr Gerontol Aging. 2016;10(2):101-11. http://doi.org/10.5327/Z2447211520161600002

18. Jorge R. Older people's preferences and priorities for end of life care in the city of Belo Horizonte, MG, Brazil [thesis]. Aveiro: Universidade de Aveiro; Porto: Instituto de Ciências Biomédicas Abel Salazar, Universidade do Porto; 2017.

19. Jorge R, Calanzani N, Freitas A, Nunes R, Sousa L. Preference for death at home and associated factors among older people in the city of Belo Horizonte, Brazil. Ciên Saúde Colet. 2019;24(8):3003-14. https:// doi.org/10.1590/1413-81232018248.24102017

20. Jorge R, Teixeira A, Calanzani N, Nunes R, Sousa L. Older people's preferences for prognostic information in a situation of serious illness with less than a year to live. Ciên Saúde Colet. 2019;24(11):4313-24. https://doi.org/10.1590/1413-812320182411.02022018

21. Abreu CBB, Fortes PAC. Questões éticas referentes às preferências do paciente em cuidados paliativos. Rev Bioét. 2014;22(2):299-308. http://doi.org/10.1590/1983-80422014222011

22. Lima MLF, Rego STA, Siqueira-Batista R. Processo de tomada de decisão nos cuidados de fim de vida. Rev Bioética. 2015;23(1):31-9. http://doi.org/10.1590/1983-80422015231043

23. Morsch P, Mirandola AR, Caberlon IC, Bós ÂJG. Factors associated with health-related decision-making in older adults from Southern Brazil. Geriatr Gerontol Int. 2017;17(5):798-803. http://doi.org/10.1111/ggi.12788

24. Bynum JPW, Barre L, Reed C, Passow H. Participation of Very Old Adults in Health Care Decisions. Med Decis Mak. 2014;34(2):216-30. http://doi.org/10.1177/0272989X13508008

25. Fried TR, O'Leary J, Van Ness P. Fraenkel L. Inconsistency over time in the preferences of older persons with advanced illness for lifesustaining treatment. J Am Geriatr Soc. 2007;55(7):1007-14. http:// doi.org/10.1111/j.1532-5415.2007.01232.x

26. Akechi T, Miyashita M, Morita T, Okuyama T, Sakamoto M, Sagawa R, et al. Good Death in Elderly Adults with Cancer in Japan Based on Perspectives of the General Population. J Am Geriatr Soc. 2012;60(2):271-76. http://doi.org/10.1111/j.1532-5415.2012.03895.x

27. Fumis RRL, De Camargo B, Del Giglio A. Physician, patient and family attitudes regarding information on prognosis: A Brazilian survey. Ann Oncol. 2012;23(1):205-11. http://doi.org/10.1093/annonc/mdr049

28. Vick S, Scott A. Agency in health care. Examining patients' preferences for attributes of the doctor-patient relationship. J Health Econ. 1998;17(5):587-605. http://doi.org/10.1016/S0167-6296(97)00035-0

29. De Vleminck A, Pardon K, Roelands M, Houttekier D, Block LVD, Stichele $\mathrm{RV}$, et al. Information preferences of the general population when faced with life-limiting illness. Eur J Public Health. 2015;25(3):53238. http://doi.org/10.1093/eurpub/cku158

30. Rede Interagencial de Informações para a Saúde. Proporção de idosos na população [Internet]. Brasília: Ministério da Saúde; 2015 [accessed on Nov. 4, 2019]. Available from: http://tabnet.datasus.gov. br/cgi/tabcgi.exe?idb2012/a14.def 